\title{
Lean Principles Application in the Automotive Industry
}

\author{
György Czifra ${ }^{1}$, Peter Szabó ${ }^{2}$, Miroslava Míkva², Jaromíra \\ Vaňová ${ }^{2}$ \\ ${ }^{1}$ Óbuda University, Bánki Donát Faculty of Mechanical and Safety Engineering, \\ Népszínház u. 8, H-1081 Budapest, Hungary, \\ E-mail: czifra.gyorgy@bgk.uni-obuda.hu \\ ${ }^{2}$ Faculty of Materials Science and Technology in Trnava, Slovak University of \\ Technology in Bratislava, ul. J. Bottu č. 2781/ 25, 91724 Trnava, Slovak \\ Republic, E-mail: peter.szabo@stuba.sk, miroslava.mlkva@stuba.sk, \\ jaromira.vanova@stuba.sk
}

\begin{abstract}
In today's competitive environment, the strategic goal of most organizations, is not only to survive, but also to move forward. It is therefore important to examine business processes and minimize waste. Anything that does not add value and contributes to unnecessarily spent funds can be considered to be a waste, so the goal of each community should be to get rid of activities that negatively affect its effective functioning. The aim of the paper is to highlight the possibilities of using Lean principles in the automotive industry. The purpose of using lean manufacturing methods is to eliminate identified shortcomings and wastage, to ensure smoother production and to meet customer requirements, and to reduce business costs and increase its competitiveness on the market. The article describes selected industrial engineering methods that deal with waste elimination (time, transport, waiting, movement, inventory), followed by an example of a specific application of Value Stream Mapping (Yamazummi chart) in automotive companies in Slovakia. This example gives space for discussion on the next direction of Lean principles usage in practice and potential benefits for the future.
\end{abstract}

Keywords: Lean Management; Lean Principles; Values Stream Mapping; Yamazumi Chart

\section{Introduction}

Today's global and turbulent environment is characterized by rapidly changing conditions. Businesses are thinking deeply about how to innovate their production processes, looking for more efficiency and quality, but they often lack specific projects and strategies to put these requirements into practice. Balog and Straka [1] notes that businesses focus its efforts on the future development of the 
company, have business strategy prepared, which should be focused on the unique production or the services with high added value.

One of the possibilities is the lean manufacturing strategy. Lean manufacturing aims to reduce costs by removing value-added activities. Based on the Toyota manufacturing system, many lean manufacturing tools (e.g. just in time, value stream mapping, etc.) are widely used in industrial manufacturing, including the automotive industry [2].

\section{Theoretical Background - Lean Management and Lean Factory}

Basics of Lean we first observed in the 50 s and 60 s of the $20^{\text {th }}$ Century in the management of the Japanese automaker, Toyota. The founder and owner of a comprehensive methodology is considered to be James P. Womack with his publication (from 1990) The Machine That Changed the World: The story of Lean Production. It is precisely J. Womack, who is considered to be the author who introduced the concept of Lean, as Toyota's production system [3].

The notion of lean has also expanded to business management as the term "Lean Management". In the literary sources we can meet with multiple definitions for lean management.

Bosenberg and Metzen [4] defines Lean Management as "complex system that includes the entire enterprise. Human is staged to the middle of the business. Its elements consist of funded spiritual principles, working principles with new insights into organization, integrating strategies for solving the core business problems, scientific-engineering methods, as well as a number of pragmatic working tools."

According to Chauhan et al., [5] lean manufacturing is a systematic method for the elimination of waste ("Muda"), wastes created through overburden ("Muri") and wastes created through unevenness in workloads ("Mura") within a manufacturing process.

According to Svozilová [6] Lean is a combination of principles and methods aimed at identifying and eliminating activities which do not bring any value in the process of product or service creation. These activities ultimately are waste products or waste.

The concept of lean is based on the production of a flexible response to customer and demand. Every employee has a great responsibility for the quality and production process. Decision-making competencies are decentralized in the lean manufacturing system so every worker has the right to interrupt production in the 
production process. Lean production management is heavily focused on maximizing customer satisfaction, which is in direct contradiction with traditional "Taylor" principles of mass production [7].

Košturiak and Frolík [8], say: "The business's sophistication means doing just the things that are needed, doing it right now, doing it faster than others, and spending less money at the same time. Lean is about increasing the company's performance by producing more than our competitors on a given site, adding a higher added value to a given number of people and devices than others, that we are making more orders at a given time, that we need less time for each business process. The lean principle of the company is to do exactly what our customer wants with a minimum number of activities that do not increase the price of the product or service. Being lean means making more money, earning it faster and making less effort."

The authors Sundar et al. [9] in their article write: Lean Manufacturing is considered to be a waste reduction technique as suggested by many authors, but in practice lean manufacturing maximize the value of the product through minimization of waste. Lean principles define the value of the product/service as perceived by the customer and then making the flow in-line with the customer pull and striving for perfection through continuous improvement to eliminate waste by sorting out Value Added activity (VA) and Non-Value Added activity (NVA). The sources for the NVA activity wastes are Transportation, Inventory, Motion Waiting, Overproduction, Over processing and Defects.

The above definitions show that the foundation of Lean Enterprise is the elimination of waste, thus losses that do not add value for the customer.

If an enterprise wants to live a lean philosophy, it cannot understand it in a limited way, it has to connect it to other sectors of its activities, starting with product development, logistics, production, as well as the slim administration itself and the overall slim understanding of the business itself. Basic elements of Lean Enterprise are shown on Figure 1.

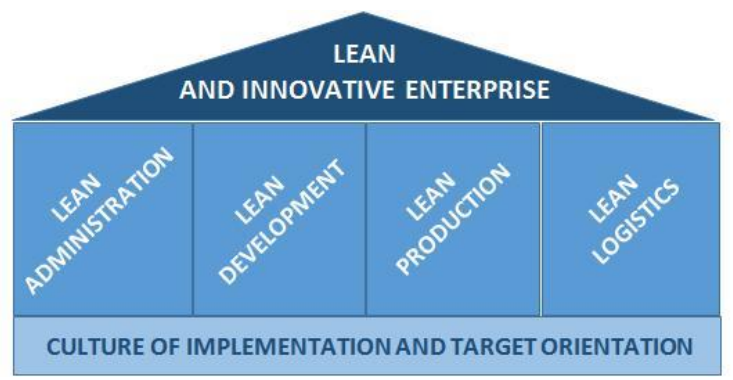

Figure 1

Basic elements of Lean Enterprise [10] 
The basic principles of lean, include [11]:

1. Understanding the concept of value from a customer perspective - it is necessary to know what is really the value for the final customer and that is important for the organization.

2. Value flow analysis - as we suddenly understand the value as understood by the customer, it is important to define correctly the value flows in the production process (again from the customer's point of view). It is necessary to determine the steps that add value and which do not need to be eliminated.

3. Fluent flow - wherever possible, a smooth flow of material is required without unnecessary buffers and w.i.p. production.

4. Pull system application - the organization does not produce to warehouse; production is conditional to customer requirements.

5. Perfection - it is necessary to reduce or completely eliminate wastage, the creation of value for the final customer should be the same or higher than its expectations.

\subsection{Lean Production Methods}

Lean manufacturing methods are the cornerstone of success for lean manufacturing in enterprises. There are several methods of lean manufacturing, the company can utilize their full range - in general, the given methods can also be understood as management or process development methods. However, it is necessary to realize that the actual implementation of individual instruments does not necessarily have to bring the desired effect to the company, as long as they do not absorb the lean manufacturing philosophy itself. It consists in the active participation of top management, on-site production management, active involvement of all employees in the enterprise in continuous improvement processes, not only at their workplace, but wherever appropriate. Lean manufacturing can be introduced with a large number of instruments, but it is important to remember that these tools are only helping tools of a sophisticated philosophy. The power of used tools in this way is a combination of their use.

\subsubsection{Value Stream Mapping}

Value Stream Mapping (VSM) or Value Stream Analysis is an analytical technique that is one of the basic methods of lean manufacturing philosophy. Based on Abdulmalek and Rajgopal [2] this map is used to identify sources of waste and to identify lean tools for reducing the waste.

Value flow is a complex package of activities that is ultimately added to the end value for the customer in the process of transforming materials to products. However, it includes activities that add and not add value to the final product [12]. 
VSM serves to describe processes that add and add value to both manufacturing, service, and administrative structures. This methodology is based on the preparation of a physical map so that all team members are directly involved in the process. Creation can be compared to a controlled brainstorming where the structure of work is defined by product flow through production and by identifying all the significant factors affecting its final form and condition [13].

There are 2 basic flows within the transformation process: 1) information flow orders against the value flow (from customer to receipt of input material) and so on, 2) material flow - products flowing in the value flow direction (from input material to product delivery to the customer) [13].

To compile the value flow map, it is necessary to measure times and steps individually and do not rely on standard times. The best solution is when the recorder observes all the steps and writes all the data, as well as the delays that may occur.

The information obtained then serves to build the map itself (Figure 2), which is divided into three parts:

- The top of the map is used for information flow

- The middle of the map is used for material flow

- The bottom of the map is used for process time recording

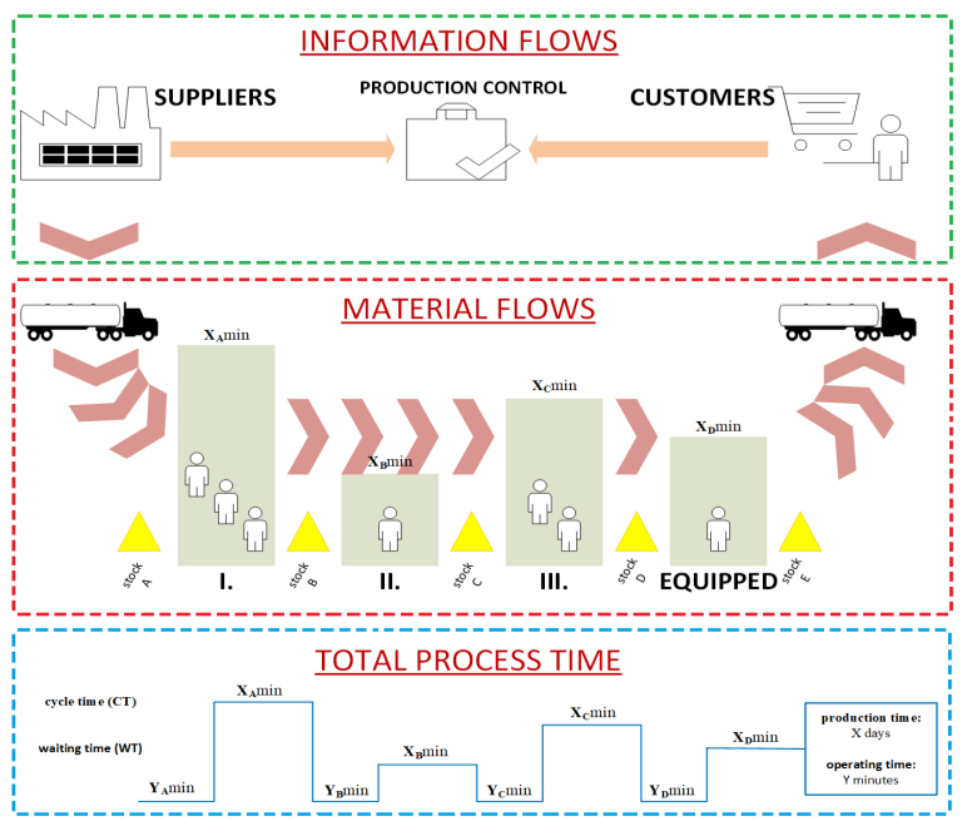

Figure 2

Value Stream Mapping (source: own processing based on [10] [14]) 
The information we receive is then written to the bottom of the map in the time zone that tells us how much time the material has been on the road and how long it has been processed.

Value stream mapping helps to identify possible losses bottlenecks, weaknesses and reasons for inefficient flows anywhere in the enterprise.

\subsubsection{Takt Time and Cycle Time}

To achieve a customer driven value stream it is important to design the production or manufacturing system to be consistent with the pace at which the customer is demanding a part or product. This pace is often referred to as the "Takt Time" [15].

Takt time or clock time is the basic indicator of lean manufacturing. Indicates the speed (tempo) that the parts are to be manufactured to meet the order. The purpose of the clock time is to precisely match production with demand. Takt time (TT) is calculated as the share of available production time and the number of pieces the customer requests [16].

Cycle time is a theoretical value. The real time value that each operator (factory worker) or machine needs to complete is a cycle time. The actual process is slowed down by ineffective actions and abnormalities that prolong our time or cycle time. The basic idea of a lean production is to approach the cycle time to the tact time so that we can "captivate to produce." The cycle time must be less than the cycle time [16].

Yamazumi chart is a Japanese method designed to visualize the time data of activities identified in the analyzed process. The data is displayed in the form of a bar graph with a color resolution of activities based on their inclusion in the identified categories.

According to Semjon \& Evin [17], the Yamazumi chart is: "a folded column graph showing the balance of the load cycle time between several operators on the assembly line. It may be made for one or more assembly line products." Sabadka et al., [18] characterize Yamazumi chart as a bar chart that shows the total cycle time for each operator when performing their process in the production flow.

In order to plan and solve the problems and then make Yamazumi, the company needs to know the assembly process in detail. It is not enough to know only the important mounting details, but they need to know the storage length of the component or how long does it take to take it out of the shelf. Also, be aware of the long way for the component. It is necessary to record how many seconds are needed to achieve the tool, such as the working times of presses, screwdrivers, welders, laminators, and the like. You should also be aware that the employee is following the work process or not. It is very important to understand the details of 
the work before it can improve the process while creating a Yamazumi chart. It allows you to create seamless, safe and efficient processes. Visualizes the current situation and highlights the critical points on the assembly operations. Helps solve problems and improves current conditions. [17]

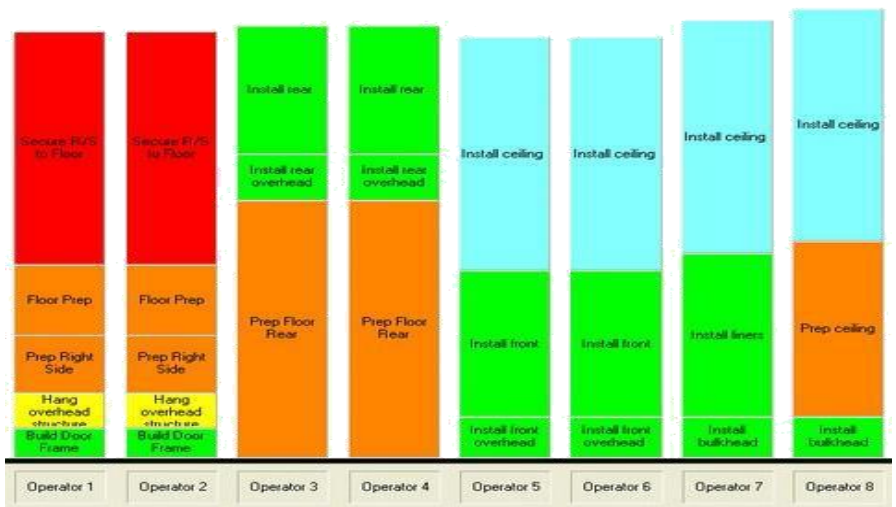

Figure 3

Yamazumi Chart Preview [17]

In practice, the Yamazumi chart can be applied on magnetic boards that are accessible and located near assembly lines. It is very important to have customer audits where it is possible to see the whole assembly process and follow it in successive sequences. Yamazumi presents a certain overview of the assembly sequence, where each part of the step is color-rendered. The graph is shown in Figure 3.

The Yamazumi graph defines and color-differentiates the type of work [17]:

Green designation - Value added work, changing form, properties and value of the product.

Orange labeling - work required, work without added value, but necessary to change shape, properties and value of the product.

Red labeling - work without added value, does not change the form, properties and value of the product.

Yellow labeling - optional work is not performed on each product and depends on the specifications - product type distinction.

Blue labeling - Various work is performed on each product, but its range and duration depend on the specifications. 


\subsubsection{Lean Layout}

Layout, as the layout of production, non-production and storage capacities in the company is undoubtedly one of the most important tasks because it has a direct impact not only on the company economy but also affects safety at work and social environment of the company [19].

Lean Layout is applying the concepts and principles of Lean to something larger than one process. Lean layout is a method of building a space-saving workplace with smooth material flows and productive production.

We consider the layout as the way the process factors are organized in the production process, and how they are redistributed into the individual process activities. Inappropriate layout can lead to too long, confusing and unpredictable flow, customer waiting, long process time, inflexible activity and high cost [20].

With a wrong arrangement of the layout we can observe the different kinds of waste, such as unnecessary handling and shipping, mistakes in production planning, stockpiling, and high rate of w.i.p., long lead time, uneven flow of semifinished products, low standardization [21].

The economy of work movements requires the observance of principles such as the use of the shortest distances; to logically place the material, tools, controls and the like in the functional area of the worker; the most used and heaviest objects are placed at the height of the work surface; the material should be stored to allow quick and easy grip. [8]

According to [20], the most important features of the lean layout to be taken into account when forming it are:

- Own security - All processes which are potentially dangerous to the customer or employee must be secure.

- The length of the flow of material, information or customers should be proportionate action. This usually means minimizing the distance that must pass. However, this is not always the case, for example in a supermarket.

- Flow transparency - Every material and customer flow should be well marked, clear and obvious to every employee and customer.

- Conditions of employees - Employees should be placed away from the noisy and unpleasant parts of the plant.

- Management coordination - Supervision and communication can help staff to be deployed and use appropriate communication facilities.

- Accessibility of maintenance - All machinery and equipment should be accessible for cleaning and maintenance. 
- Usage of space - Space should be used appropriately. This usually means minimizing space. However, for example, luxury hotels need to create a sense of importance and luxury.

- Long-term flexibility - the layout needs to be changed periodically. A good layout is designed to flexibly change with future needs.

\subsubsection{Lean Controlling}

Management activities in corporate governance are derived from strategy definition (in the form of a strategic plan), followed by operational plans (marketing, sales, finance, human resources, innovation, manufacturing etc.) control future deviations from the stated objectives is the responsibility of controlling bodies (sometimes as part of financial department), which are usually responsible for the management of the risks arising from the deviations found in the small and medium-sized firm as well. Since each plan (strategic and operational) must have defined goals, controlling is also focused on the detection and subsequent management of specific strategic and operational objectives. [22]

Many companies in the manufacturing and process industry have fully embraced the lean management philosophy; their finance and controlling departments, however, are still stuck in a 1920s approach to standard cost calculation. Outdated structures and systems need to adapt to changing requirements and reflect new challenges in production control.

Lean Controlling increases transparency while reducing complexity at the same time. It is based on the following premises [23]:

- Cost optimization with a focus on customer benefit

- More efficient and robust processes with a higher degree of automation

- Leveraging of information that is truly relevant to the steering and controlling process

- A holistic approach to control the value chain based on flow metrics

Lean controlling means transmitting ideas and fundamental elements of lean manufacturing to controlling. These include, in particular, the realization of kaizen thinking, the reduction of the depth of production (Outsourcing), the closer relations with the suppliers as well as the strong process orientation of the company.

New controlling objects are processes at different hierarchical levels (e.g., major or partial processes) and should also become subject(s) of planning and management activities. Implementation of Kaizen also affects the content of controlling. Instead of deviations, the prevention of waste or the assessment of continuous improvement in the production process will be the focus of controlling activities [24]. 
In the context of lean controlling, controlling efficiency is basically the relationship between controlling outputs and the objectively spent time and cost involved. Lean controlling creates transparency through Lean Produktion \& Lean Office. The main task of lean controlling is to highlight the "Black Hole" costs of waste and non-value creation activities, as well as to improve through lean methods [25].

The most important change must be in thinking: Englishmen call it "mindset change". The intent of Lean controlling is to ask: is the statistics, records or report required by us, or we add value to it? If so, we will do our best, if not, to prevent this requirement from arising in the future, so that we can concentrate on a real role: to uncover sources of losses and eliminate them through controlling tools [26].

Benefits resulting from the application of lean controlling methods for individual business areas [23]:

- For accounting - optimize cash flows

- For operational controlling - full transparency in the calculation of materials and production costs

- For strategic controlling - embed strategy within budgeting and forecasting processes

- For lean transformation - drive organizational change towards a culture of continuous improvement

\section{Data and Research Methodology}

In terms of lean manufacturing, we have mentioned some of the lean manufacturing methods used in automotive companies in Slovakia in previous chapters. The results presented are based on the research tasks carried out in industrial enterprises belonging to the automotive segment and their supply chains. The survey was conducted on a sample of 17 enterprises selected by random selection. The goal of the questionnaire was to determine the level of knowledge and use of lean methods in order to make production processes more efficient. With respect to uniform standards and standards used in automotive, we consider the differences in the application of these methods to be negligible.

The results are shown in Figure 4. We approached this insight based on the longterm analysis and experience from industrial organizations within cooperation and based on a survey conducted in the framework of the research projects. 


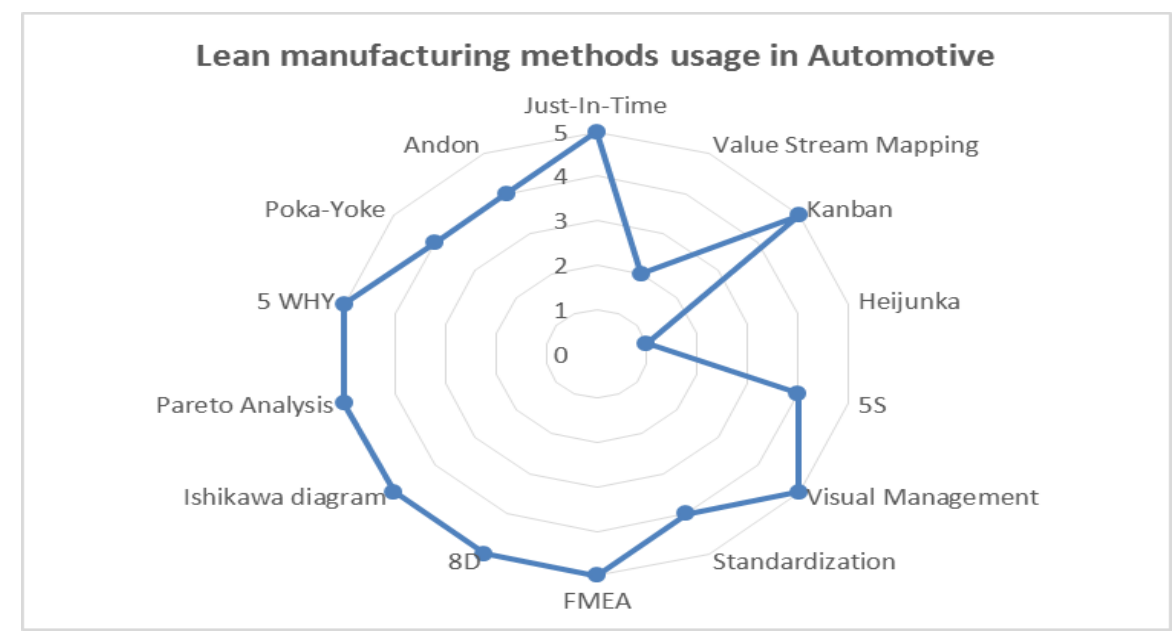

Figure 4

Lean manufacturing methods usage in Automotive (source: own processing based on several surveys)

For each method, we stated value of $1-5$, the values mean:

5 It is used throughout the company on a regular basis

4 It is used regularly in the selected department

3 Used in part, insufficiently, without planning or evaluation

2 Used in the past, but no longer

1 Not used at all and never used

From the graph (Figure 4) we have shown that methods such as Ishikawa Diagram, Pareto Analysis, 5W, 8D, FMEA Visual Management, Just in Time and Kanban are used in the automotive industry sufficiently, which may either be their simplicity of application, or relation to the requirements of standards that are obligatory on the automotive industry. Method Heijunka the surveyed enterprises due to its nature, is not used. Method 5S and its related Standardization is used in enterprises, but in some cases only in selected workplaces. The VSM method is poorly utilized in the enterprises surveyed.

In the next part of the case study, we point out the importance and need for applying this method in enterprises, as this method serves to map the value flow and makes it possible to identify the causes of unnecessary waste of resources (time, human labor, material, information or financial). VSM helps to identify possible losses, bottlenecks, and inefficient flows anywhere in the business. 


\section{Application of Lean Manufacturing Methods - Company Case Study}

No production is $100 \%$ fluent and does not work without downtime. It means waiting, that is, waste in production, which can lead to failure to meet the required supply of manufactured pieces and stop production at the customer. This part of the paper will deal with the analysis of the use of lean manufacturing methods for component manufacturing - characterized as assembly. Analyzed production can be characterized as manual - without the use of machinery. The analysis was processed using the VSM method, with a map of the current material and information flow of production shown in Figure 5.

The map (see on Figure 5) shows the production process at individual assembly stations on two parallel lines, where two components are made, forming one unit after their subsequent assembly. For each station, the following basic parameters are selected: TT (Target Cycle Time), CT (Cycle Time), Utilization, Shifts and WIP (Work in progress - processed production, pieces). TT and TCT are given by calculation, Cycle time represents the real time of the operation calculated using a predetermined time method (MOST + tracking time on lines). These data provide an overview of the difference between Target Operating Time (TCT) and Real Time on Line (CT).

These data inform about what are the time losses and differences between the different assembly station. Percentage utilization of operators on the line shows how real workloads are performed by operators at the station concerned.

Results from VSM have revealed areas of production that cause losses and waste and which need to be further targeted. These are the following:

- The high proportion of non-value adding (NVA) time for the assembly process - the linearity difference (TCT) and the real time of operation (CT) is high.

- This also means low / too high percentage of operators on the line.

- Stocks of finished components are high - the second line has no inventory. 


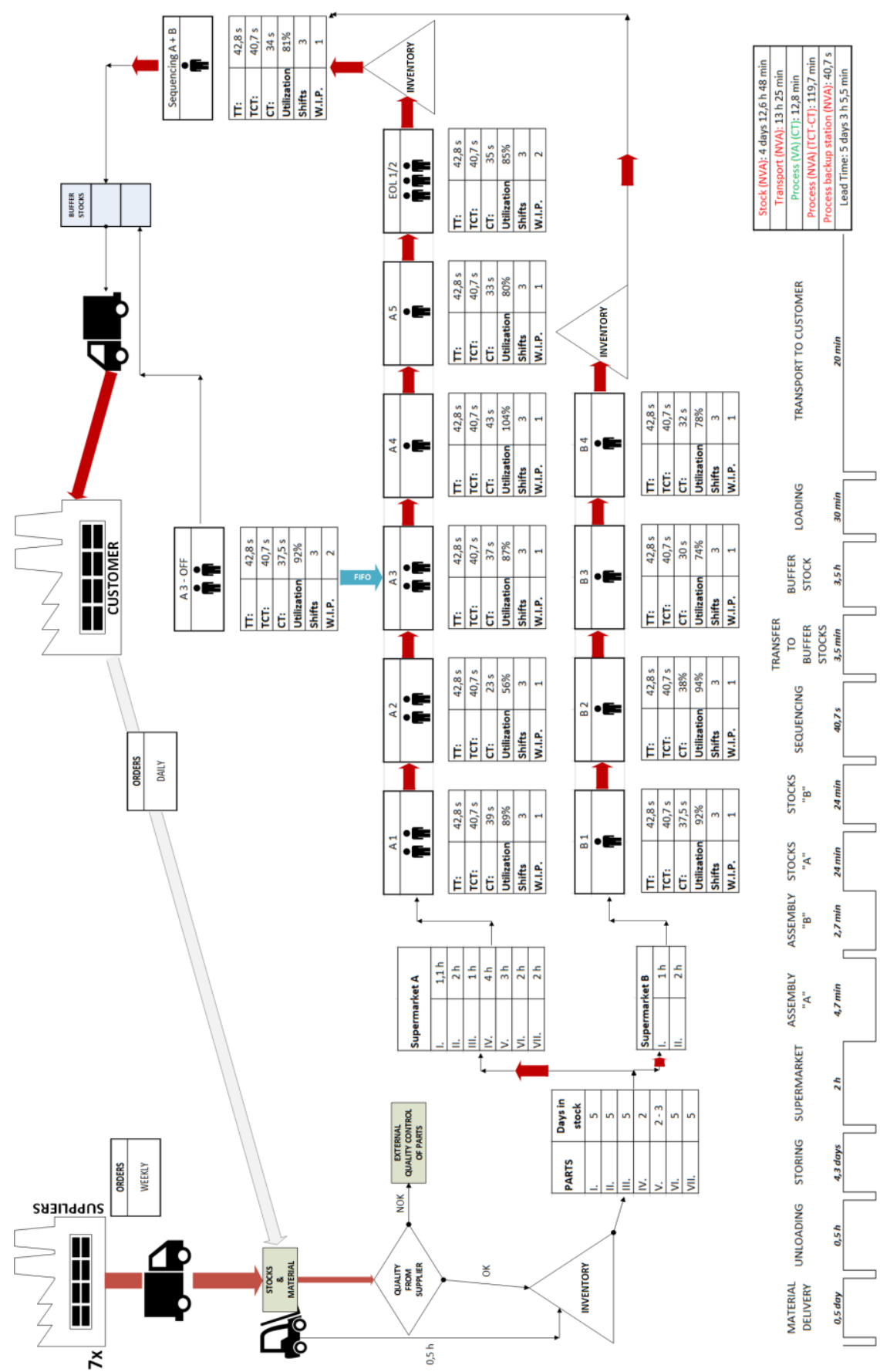

Figure 5

Value Stream Mapping - original state (source: own processing based on company internal materials) 
In particular, we focused directly on the lines, i.e. to identify the cause of the high difference CT versus TCT. Due to the difference in times, it is necessary to analyze the possibility of balancing operations between stations, consequently the need to re-evaluate the number of operators on both lines, their operational utilization, and also the type of activities performed by the operators in the operation.

A detailed timing analysis of activities at individual stations was transferred to the graphical form - the Yamazumi chart (Figure 6). This chart shows all the times of the operations performed within the operation, redistributed between components "60" and "40" (when two operators are working on the station). By cumulating the individual activity times, we receive the cycling time of the entire operation (CT). The individual activities are color-coded (NVA activities - red, VA activities green and necessary work, but no added value - yellow).

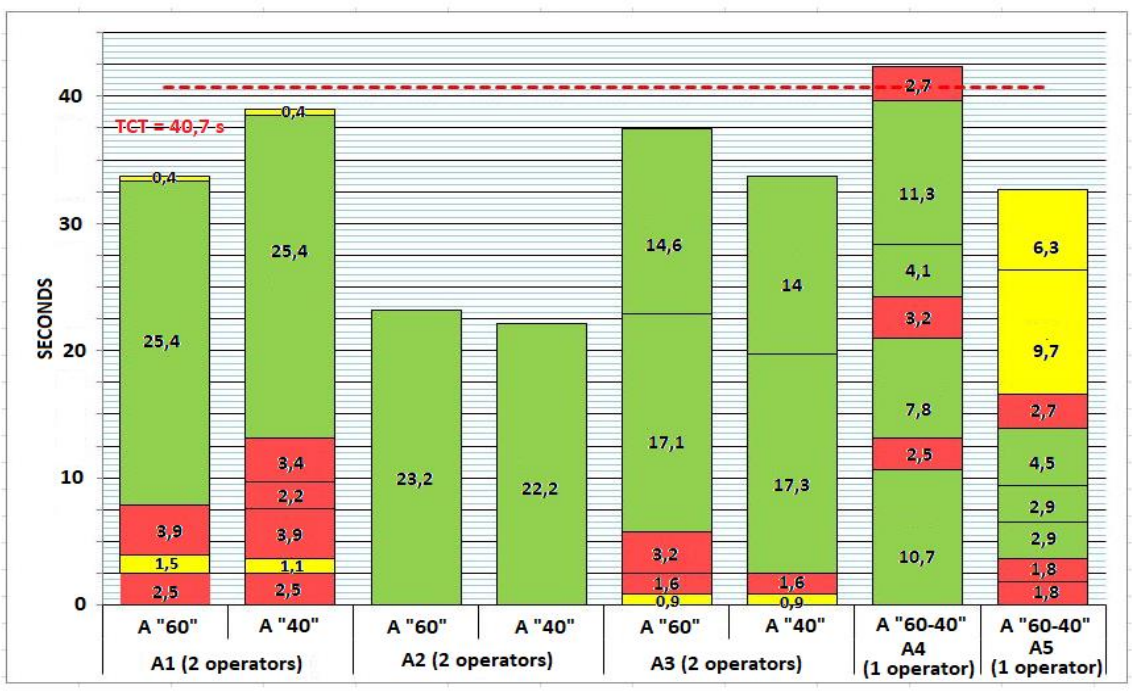

Figure 6

Yamazumi chart of production line A - original state (source: own processing based on company internal materials)

The chart provides an overview of adding value activities and activities that do not add value to the assembled component. The chart and individual actions show that the station operator A1 takes a lot of time walking the material and scanning material - NVA activities. At station A2, operators do not perform any NVA activities. It is necessary to review this operation and see if it is possible to prosecute it to perform only one operator on both components. The A4 station is the Bottleneck station (the longest installation station, heavy duty). Several subactivities are carried out on it, as on station A5, which has a certain time-off against the production cycle. 
On-site observation confirmed that at station A1, operators must walk longer distances during assembly time, especially for parts. The station A2 are compared to the operators of the completed operation in advance, and are waiting to complete the cycle. A detailed analysis of operations and tracking on the line allowed us to identify the activities that need to be focused on streamlining the production process (e.g. walking on material), as well as potential options for better unbalance of individual line A operations (in particular A2 and A4 operations). By analyzing the individual activities, we identified the potential improvement points that are shown in the new, optimized VSM diagram (see Figure 7). The changes listed below lead to the elimination of ineffective and noncreasing time values and to better utilization of the operators' workforce on the line.

Optimization of time on line A will not be done without changing the original layout of the production line, due to the shortening of operator walks, the demanding translation of parts and the saving of human work. The change of layout is based on the deficiencies and wastage found on the A1 station, which was needed outside the line - as an offline station. For this reason, assembly from station A2 has moved to station A1. As a result, station A2 became empty station and was omitted from the new layout. A FIFO stack for individual parts was placed between the A1 OFF and A1 stations.

Following the optimized VSM, a modified Yamazumi chart (Figure 8) has been developed to illustrate the time structure of all operations in the structure of times of effective operations (green color), times of required operations without added value (yellow color) and times of ineffective actions (red color).

It is clear from the graph that after the proposed reorganization of the work of the individual workplaces, the use of the operators' work is increased, in addition, the inefficient times for the assembly of individual parts have been significantly reduced, leading to an increase in the overall efficiency of production on line A.

The proposed new status brings benefits not only in reducing NVA times and achieve standard use of the work of operators, but also in reducing the number of operators required to achieve the production volume. At A1 Station OFF, unnecessary walking was reduced and the time required for installation was saved. Due to the time saved at this station, a time reserve for the line tact time was created. 


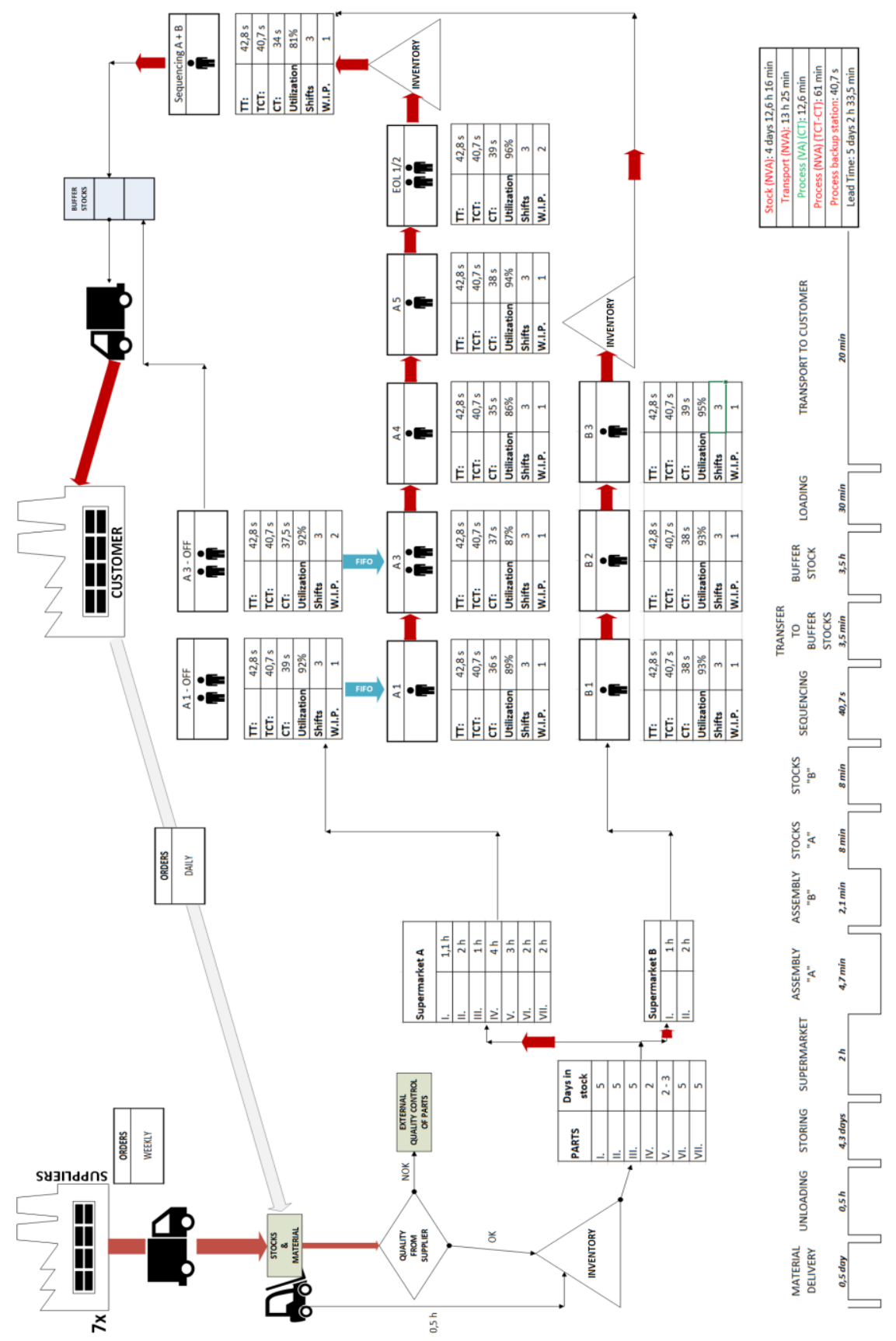

Figure 7

Value Stream Mapping - proposed state (source: own processing based on company internal materials) 


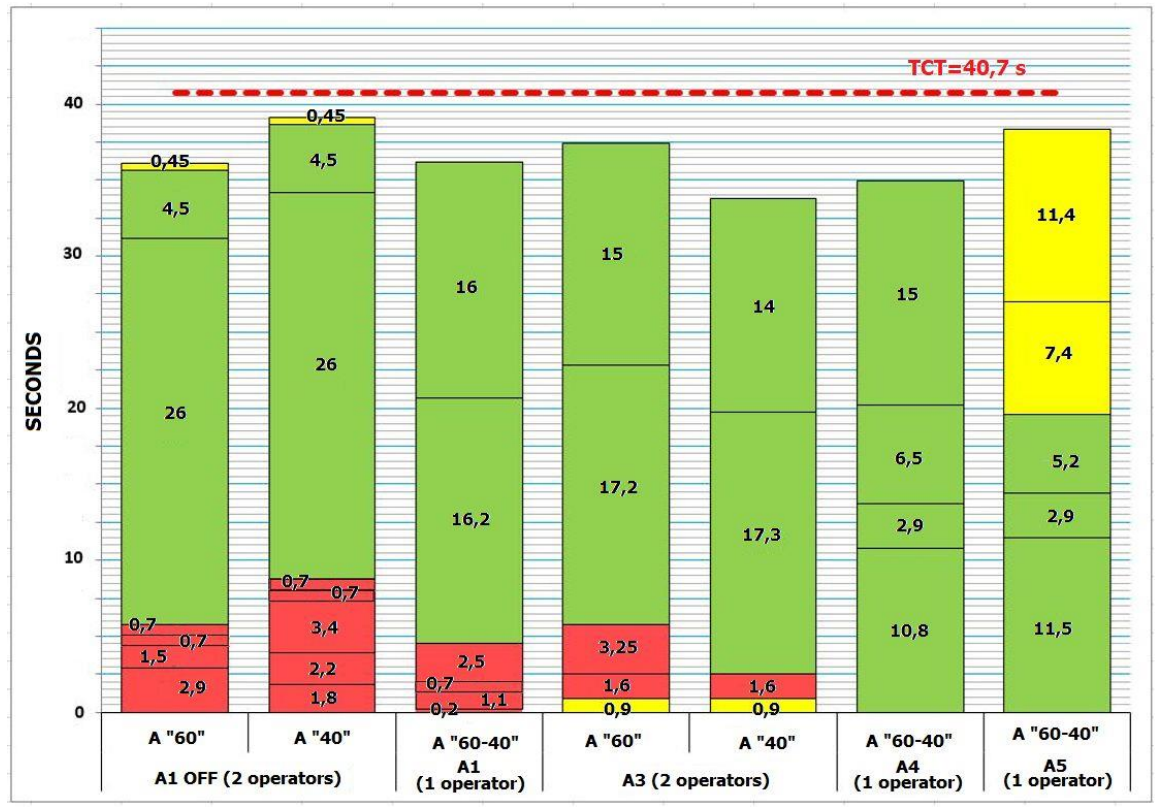

Figure 8

Yamazumi chart of production line A - proposed state (source: own processing based on company internal materials)

\section{Results and Discussion}

The main objective of the overall design of streamlining is to eliminate identified shortcomings and waste, to ensure smoother production and meet customer requirements, and to reduce the business costs of all 7 basic types of waste, the proposed solutions reduce unnecessary movements, handling, unnecessary processes, and excess inventory. In addition, the solution proposal has been able to unbalance the use of operators' working hours at individual stations of assembly lines. The result is the most balanced utilization of individual operators to the required values $(85-95 \%)$.

In general, the benefits of lean manufacturing are reduced inventory, less process waste, less rework, reduced lead time, financial saving and increase process understanding.

The main benefits of the proposal for making the layout more efficient are the follows:

- Reduction of unnecessary walking and manipulation at the current assembly stations of both lines 
- Reduction of surplus stocks of finished products

- Improving ergonomic conditions when performing operations on stations A1 and A5.

The proposed layout streamlining is a change that leads to a reduction in the time that does not add value to the resulting product, to ensuring that the standard values of the operator's percentage usage are achieved, and to reducing the number of operators and reducing the production time.

\section{Conclusion}

The implementation of Lean Manufacturing, in business, is a strategic decision of the company's Top Management. Management makes this decision based on certain expectations of this type of change. Lean production is not just a set of methods and tools, it offers much more. Lean manufacturing has to be understood as a philosophy and discipline that must be rooted in every employee, from senior management to the manufacturing workers on the line. This idea is based on continuous improvement (Kaizen) - the company should constantly strive to make production more efficient, improve processes, improve working conditions and all activities that lead to the enhancement and achievement of better lean production.

\section{Acknowledgement}

This paper was supported by the Grant Agency of the Ministry of Education, Science, and Research of Slovak Republic Projects VEGA 1/0348/17 "The impact of the coexistence of different generations of employees on the sustainable performance of organizations" and also VEGA 1/0218/16 "The model of the implementation of controlling as a management tool within small and medium enterprises in the engineering and electronics industries“".

\section{References}

[1] BALOG, Michal; STRAKA, Martin. Application of the logistics principles for the company Omega, sro in crisis time. Acta logistica, 2014, 1.1: 17-21

[2] ABDULMALEK, F.A.; RAJGOPAL, J., (2007) Analyzing the benefits of lean manufacturing and value stream mapping via simulation: A process sector case study. International Journal of production economics, 2007, 107.1: 223-236, https://doi.org/10.1016/j.ijpe.2006.09.009

[3] SAYER, N. and WILliAMS, B. (2011) Lean For Dummies. Hoboken: John Wiley \& Sons, Inc., 2011, ISBN: 978-1-118-05118-4

[4] BOSENBERG D., METZEN H., (1997) Lean Manažment: Náskok pomocou štíhlych konceptov. Bratislava, Vydavatel'stvo SLOVO. 272s. ISBN 85711-16-8

[5] CHAUHAN, P., et al., (2015) Application of Lean Manufacturing Principles for Process Time Reduction-A case of Conveyor Pulley Manufacturing, In: Proceedings of $5^{\text {th }}$ National Conference on Recent Advances in Manufacturing (RAM-2015) 2015, pp. 423-428 
[6] SVOZILOVÁ, A., (2011) Zlepšováni podnikových procesů. Praha: Grada, ISBN 978-80-247-3938-0

[7] KEŘKOVSKÝ, M., (2009) Moderni př́stupy k ř́zeni výroby. Vydavatel'stvo H.C.Beck, Praha 2009, 2. vydanie, ISBN 978-80-7400-119-2

[8] KOŠTURIAK, J., FROLÍK. Z., (2006) Štíhlý a inovativni podnik. Praha : Alfa Publishing, s.r.o., 2006, ISBN 80-86851-38-9

[9] SUNDAR, R.; BALAJI, A. N.; KUMAR, RM Satheesh. A review on lean manufacturing implementation techniques. Procedia Engineering, 2014, 97: 1875-1885, https://doi.org/10.1016/j.proeng.2014.12.341

[10] DLABAČ, J. (2014) Štíhly materiálový tok. In: Štíhla výroba a logistika [online]. Praha: Strojárenský mesačník MM. Kód článku: 140430. s.14 [cit. 2018-04-03] Dostupné na internete: http://www.mmspektrum.com/clanek/stihly-materialovy-a-hodnotovytok.html

[11] WOMACK, J. P. - JONES, D. T.: Lean Thinking. $2^{\text {nd }}$ Edition, Free Press New York, 2003, ISBN 0-7432-4927-5

[12] ONOFREJOVÁ, D. (2015) Mapovanie hodnotového toku a významnost' vo výrobnom procese [online]. Transfer inovácií. [cit. 2018-04-15] Retrieved from: https://www.sjf.tuke.sk/transferinovacii/ pages/archiv/ transfer/322015/pdf/195-198.pdf

[13] SALAJ, M. (2010) Mapovanie hodnotového toku - value stream mapping [online] [cit. 2018-05-30] from: http://www.leanportal.sk/Files/Modely/Mapy\%20hodnotovych\%20tokov.pdf

[14] Mapovanie hodnotového toku. Value Stream Mappping [online] [cit. 2018-0629] Retrieved from https://www.ipaslovakia.sk/files/6314najlepsiepraktikymetodymapovanietokuhodnot

[15] FEKETE, M., HULVEJ, J. (2013) „Humanizing“ Takt Time and Productivity in the Labor - Intesive Manufactoring Systems [online] Zadar, Croatia International Conference 2013 [cit. 2018-05-16] ISBN 978-961-6914-02-4. Dostupné na internete: http://www.toknowpress.net/ISBN/978-961-6914-024/papers/ML13-245.pdf

[16] ČERVINKA, M. (2013) Takt time [online] Portál Štíhla výroba [cit. 2018-0516] Dostupné na internete: http://www.stihlavyroba.sk/2013/04/takt-time.html

[17] SEMJON V. and EVIN. E., (2009) Increasing the productivity of the assembly line by balancing of assembly stations using the Yamazumi method. Transfer Inovácií 13, 2009, 73-77 
[18] SABADKA, Dušan, et al. Optimization of Production Processes Using the Yamazumi Method. Advances in Science and Technology. Research Journal, 2017, 11.4: 175-182, DOI: https://doi.org/ 10.12913/22998624 /80921

[19] ŠIMKO, D. Methods of distribution, layout and hungarian method. METHOD. Acta logistica, 2016, 3.1: 9-13

[20] Lean Layout [online] IPA Slovakia [cit. 2018-05-17] Retrieved from: https://www.ipaslovakia.sk/sk/ipa-slovnik/lean-layout

[21] MAŠÍN, I., VYTLAČIL, M. (1996) Cesty k vyšši produktivitě. Liberec: Institut průmyslového inženýrství. s. 55-56, ISBN 80-902235-0-8

[22] HAVLÍČEK, K. (2011) Manažment \& controlling malé a střední firmy. 1. vydání. Praha: Vysoká škola finanční a správní, o.p.s., 2011, 212 s. Edice EUPRESS. ISBN 978-80-7408-056-2

[23] The efficient way to control Lean Management [online] [cit. 2018-05-17] Retrieved from https://www.camelot-mc.com/en/client-services/financeperformance-management/lean-controlling/

[24] Lean Controlling [online] [cit. 2018-05-17] Retrieved from: http://www.betriebswirtschaft-lernen.net/erklaerung/lean-controlling/

[25] Lean Controlling. Integraler Bestandteil einer Lean Tansformation [online] [cit. 2018-05-17] Retrieved from: https://www.iqxperts-consulting.com/leancontrolling.html

[26] Mitöl lesz egy megoldás lean? És mi köze ennek a controllinghoz? What makes a solution lean? And what has this to do the controlling? [online] [cit. 2018-0629] Retrieved from https://www.controllingportal.hu/ mitol_lesz_egy_megoldas/ 